Indonesian Journal of Counseling and Development p-ISSN: 2685-7375 | e-ISSN: 2685-7367

Vol. 01, No. 02, Desember 2019, pp. 141-149

\title{
Pengaruh Konseling Kelompok Menggunakan Pendekatan Cognitive Behavior Therapy untuk Meningkatkan Kontrol Diri Siswa
}

\author{
Desi Ermayulis ${ }^{1}$, Masril 2, dan Emeliya Hardi ${ }^{3}$ \\ Institut Agama Islam Negeri (LAIN) Batusangkar \\ e-mail: emeliyahardi@iainbatusangkar.ac.id
}

\begin{abstract}
The main problem in this study is the lack of self-control of students in class XI IPS SMAN 1 Batipuh. The purpose of this study was to see how much influence the group counseling approach to Cognitive Behavior Therapy to improve self-control of students of class XI IPS SMAN 1 Batipub. This type of research is quantitative research using experimental methods. The design used in this study was pre-experimental design with the type of one group pretest-posttest design, namely by measuring the self-control of the experimental group students by using the same instrument in the pretest and posttest measurements. The population in this study were all students of class XI IPS SMAN 1 Batipuh, the sample in this study were 10 students who have low self-control. The results showed that cognitive behavior therapy approach group counseling had a significant effect on student self control. This can be seen based on the results of " $t$ " count with $d f$ or $d b 9$, with a significance level of $0.5 \%$ obtained that (16.8)> tt (1.83) can thus be interpreted that the cognitive behavior therapy approach group counseling influential significant to the self-control of students of class XI IPS at SMAN 1 Batipuh.
\end{abstract}

Keywords: Group Counseling Cognitive Behavior Therapy Approach, Self Control

Abstrak. Masalah pokok pada penelitian ini adalah kurangnya kontrol diri siswa di kelas XI IPS SMAN 1 Batipuh. Tujuan penelitian ini untuk melihat seberapa besar pengaruh konseling kelompok pendekatan Cognitive Behavior Therapy untuk meningkatkan kontrol diri siswa kelas XI IPS SMAN 1 Batipuh. Jenis penelitian ini penelitian kuantitatif dengan menggunakan metode eksperimen. Desain yang digunakan dalam penelitian ini adalah pre-eksperimental design dengan tipe one group pretest-posttest design yaitu dengan mengukur kontrol diri siswa kelompok eksperimen dengan menggunakan instrumen yang sama pada pengukuran pretest dan posttest. Populasi dalam penelitian ini adalah seluruh siswa kelas XI IPS SMAN 1 Batipuh, sampel dalam penelitian ini sebanyak 10 orang siswa yang mempunyai kontrol diri rendah. Hasil penelitian menunjukkan bahwa konseling kelompok pendekatan cognitive behavior therapy berpengaruh signifikan terhadap kontrol diri siswa. Hal ini dapat dilihat berdasarkan hasil " $\mathrm{t}$ " hitung dengan df atau db 9, dengan taraf signifikansi 0,5\% diperoleh hasil bahwa $\quad(16,8)>$ tt $(1,83)$ dengan demikian dapat diartikan bahwa konseling kelompok pendekatan cognitive behavior therapy berpengaruh signifikan terhadap kontrol diri siswa kelas XI IPS di SMAN 1 Batipuh.

Kata Kunci: Konseling Kelompok Pendekatan Cognitive Behavior Therapy, Kontrol Diri 


\section{PENDAHULUAN}

Manusia dalam kehidupannya, perlu memiliki kontrol diri dan harus bisa mengendalikan dirinya dengan baik. Jika manusia tidak bisa mengendalikan diri dengan baik, maka kehidupannya tidak akan terarah. Chaplin (dalam Rahmawati, 2013:7) mengatakan bahwa "kontrol diri adalah kemampuan untuk membimbing tingkah laku sendiri, kemampuan untuk menekan atau merintangi impuls-impuls atau tingkah laku impulsif'. Sejalan dengan itu, menurut Khairunnisa (2013:2) "kontrol diri adalah keyakinan individu bahwa tindakannya akan mempengaruhi perilakunya, dan individu sendiri yang dapat mengontrol perilaku tersebut". Di sisi lain Calhoun dan Acocella mendefenisikan "kontrol diri sebagai pengaturan proses-proses fisik, psikologis, dan perilaku seseorang. Dengan kata lain serangkaian proses yang membentuk dirinya". Kontrol diri (self control) merupakan salah satu kebutuhan remaja yang harus dipenuhi. Remaja membutuhkan kontrol diri karena remaja pada umumnya berada pada masa badai dan tekanan. Remaja berada pada masa badai dan tekanan (strom and stress) karena remaja telah memiliki keinginan bebas untuk menentukan nasib sendiri, jika terarah dengan baik maka ia akan menjadi seseorang yang memiliki rasa tanggung jawab, namun jika tidak maka ia bisa menjadi seseorang yang tidak memiliki masa depan yang baik. Tidak seluruh remaja mengalami masa badai dan tekanan namun lebih besar kemungkinannya terjadi pada masa remaja.

Seharusnya remaja sudah mempunyai kemampuan yang baik dalam mengontrol dirinya, namun dalam kehidupan sekarang banyak ditemui remaja yang tidak mampu mengontrol sikap dan perilaku yang dimilikinya. Selain itu pada masa remaja ini banyak terjadi perubahan pada bentuk fisik remaja yang akan mempengaruhi sikap dan perilakunya, pada saat sekarang banyak remaja yang tidak bisa mengontrol dirinya, disaat terjadi perubahan tersebut, ada remaja stress akibat perubahan tersebut, maka diperlukan kontrol diri yang baik agar remaja bisa menyikapi persoalan yang dihadapinya. Kendali diri atau pengendalian diri erat kaitannya dengan kondisi emosional seseorang, individu yang pandai mengelola emosi dapat mengendalikan diri dengan baik.

Fenomena yang terjadi pada saat sekarang siswa kurang bisa mengontrol diri dalam aspek perilaku seperti sering tidak buat tugas, sering bolos sekolah, sering terlambat, dan dari segi emosinya siswa pada saat sekarang sering merasa cemas bila terlambat atau tidak buat tugas sehingga siswa mencari alasan agar tidak diberi hukuman, kemudian pada saat sekarang siswa kurang bisa mengontrol emosinya dengan baik, misalnya apabila seorang teman yang memperolok-olok kan dirinya maka secara tidak langsung mereka ada yang langsung membalas dengan kekerasan fisik. 
Berdasarkan hasil wawancara penulis dengan salah seorang guru BK di SMAN 1 Batipuh pada hari Senin tanggal 12 September 2018, bahwa siswa di sana dalam hal kontrol diri masih kurang karena setiap hari masih banyak siswa yang tidak masuk kelas pada saat jam pembelajaran berlangsung dan pergi ke kantin, siswa tersebut memberikan alasan karena mereka lapar dan ingin menenangkan pikiran karena banyak nya pelajaran yang harus di terima pada hari itu. Mereka berpikir apa yang mereka lakukan itu adalah hal yang wajar saja karena mereka keluar ruangan dan pergi ke kantin itu hanya untuk mengisi perut yang kosong dan untuk menenangkan diri sejenak. Kemudian setiap harinya juga masih banyak siswa yang terlambat, dengan alasan karena susahnya transportasi untuk menuju kesekolah. Mereka berpikir bahwa terlambat merupakan hal biasa karena mereka terlambat bukan keinginan dari mereka sendiri tetapi karena susahnya transportasi untuk kesekolah. Penulis juga melakukan observasi di lapangan pada hari Senin, tanggal 12 September 2018 bahwa siswa di SMAN 1 Batipuh khususnya kelas XI IPS memang kurang dalam mengontrol dirinya, hal ini dapat dilihat ketika guru menerangkan pelajaran di kelas masih ada siswa yang tidak memperhatikan malah sibuk dengan aktivitasnya sendiri. Ketika pelajaran matematika siswa ada yang membuat tugas ekonomi.

Pada masa remaja akan terjadi kematangan kognitif, dimana remaja akan mampu berpikir tentang apa yang terjadi pada diri mereka dan mampu mencari alternatif pemecahan masalahnya. Namun yang terjadi pada saat sekarang remaja tidak mampu berpikir dengan baik baik sehingga terjadilah perilaku yang tidak diinginkan. Juga remaja pada masa remaja sekarang banyak ditemui yang tidak bisa mengontrol emosinya dengan baik, mereka seringkali terbawa emosi sehingga yang terjadi malah perkataan-perkataan yang buruk terhadap orang lain.

Dalam hal ini penulis mencoba meningkatkan kontrol diri dengan konseling kelompok pendekatan cognitive behavior therapy. Pendekatan cognitive behavior therapy merupakan sebuah pendekatan dalam konseling yang di pelopori oleh Beck. Menurut Beck (dalam Habsy , 2017:4) Asumsi dasar konseling cognitive behavior therapy bahwa tingkah laku individu yang terlihat (overt behavior) dipengaruhi oleh proses kognitif. Konseling ini tidak hanya berfokus pada perubahan tingkah laku, akan tetapi lebih pada adanya distorsi kognitif pada individu untuk penyelesaian permasalahan.

Berdasarkan pendapat di atas dapat di pahami bahwa tingkah laku seorang individu yang terlihat didalam kehidupan sehari-harinya merupakan hal yang dipengaruhi oleh proses berpikirnya. Ketika seorang individu bertingkah laku maka ia juga berpikir, dan tingkah laku yang dihasikan tersebut merupakan hasil dari proses berpikir. Diperkuat lagi oleh asumsi Beck (dalam Darimis, 2014:185) menyatakan bahwa: 
Dampak berpikir terhadap tingkah laku dan kepribadian secara luas, meskipun gangguan kognitif tidak dianggap gangguan psikologis, namun hal itu menjadi komponen bagi cognitive behavior therapy. Artinya, pikiran otomatis yang tidak disadari bisa mempengaruhi perkembangan kepribadian. Pikiran seperti itu merupakan aspek keyakinan individu (skema kognitif) yang menjelaskan bagaimana individu membuat pilihan dan menarik kesimpulan tentang kehidupan mereka. Selanjutnya menurut Gladding (dalam Darimis, 2014:185) bahwa: "Bagaimana seseorang menjelaskan situasi pada umumnya terlihat pada kognisinya (pikiran dan gambaran visual).Oleh karena itu tingkah laku yang tidak fungsional disebabkan oleh pikiran yang tidak fungsional, jika keyakinan tidak diubah, tidak ada kemajuan dalam tingkah laku, jka keyakinan berubah, tingkah laku juga berubah".

Adapun dalam penelitian cognitive behavior therapy ini penulis menggunakan teknik thought stopping. Menurut Nursalim (2013), teknik thought stopping merupakan teknik yang digunakan untuk membantu ketidakmampuan seseorang dalam mengontrol pikiran dan gambaran- gambaran dari diri dengan cara menekan atau menghilangkan kesadaran- kesadaran negatif tersebut. Triyono (1994) menyatakan bahwa teknik thought stopping merupakan salah satu bentuk konseling tingkah laku kognitif yang digunakan untuk mengatasi pikiran yang tidak rasional yang membuat masalah bagi seseorang yang terlalu memusatkan pada hal tersebut sehingga dapat membantu konseli untuk mengontrol pikiran yang tidak sesuai atau tidak produktif melalui menekan atau membatasi.

Menurut Cormier \& Sherlyn (dalam Setiawati, 2015: 10) "thought stopping adalah suatu teknik yang dapat digunakan untuk mengontrol pikiran klien yang tidak produktif atau pikiran pada dirinya sendiri dan gambaran negatif'. Hana (dalam Setiawati, 2015: 10) mengemukakan bahwa "teknik thought stopping adalah suatu teknik untuk mengatur pikiran negatif". Faruq (dalam Setiawati, 2015: 10) juga mengemukakan bahwa "teknik thought stopping merupakan salah satu teknik dalam pendekatan konseling kognitif behavioral yang digunakan untuk mengubah pikiran negatif seseorang menjadi pikiran yang positif'.

Jadi dapat disimpulkan bahwa teknik thought stopping adalah suatu teknik dalam pendekatan konseling untuk mengontrol pikiran klien dimana pikiran negatif klien akan di ubah menjadi pikiran yang positif, dengan cara menekan atau membatasi pikiran tersebut.

Berdasarkan latar belakang di atas maka penelitian yang diteliti tentang "Pengaruh Konseling Kelompok Pendekatan Cognitive Behavior Therapy untuk Meningkatkan Kontrol Diri Siswa Kelas XI IPS SMAN 1 Batipuh”. 


\section{METODE}

Jenis penelitian ini adalah penelitian kuantitatif dengan menggunakan metode eksperimen. Jenis desain yang digunakan dalam penelitian ini adalah pre-eksperimental design dengan tipe one group pretest-posttest design yaitu dengan mengukur kontrol diri siswa kelompok eksperimen dengan menggunakan instrumen yang sama pada pengukuran pretest dan posttest. Instrumen yang digunakan adalah instrumen skala kontrol diri model guttman. Populasi dalam penelitian ini adalah seluruh siswakelas XI IPS SMAN 1 Batipuh, sampel dalam penelitian ini diperoleh melalui teknik purposive sampling, sebanyak 10 orang siswa yang mempunyai kontrol diri rendah.

\section{TEMUAN}

Berdasarkan tujuan penelitian hasil yang diperoleh dari penelitian adalah terdapat pengaruh signifikan konseling kelompok pendekatan Cognitive Behavior Therapy untuk meningkatkan kontrol diri siswa. Setelah dianalisis terdapat 10 orang siswa yang memiliki kontrol diri rendah. Peneliti menyebarkan instrumen kontrol diri kepada 86 orang siswa kemudian ada 10 orang yang memiliki kontrol diri kategori rendah. Terlebih dahulu instrumen tersebut telah dilakukan validitas dan reliabilitas, dan di dapat hasilnya valid dan reliabel, dan didapat instrumennya sebanyak 32 item dengan 2 Indikator yaitu kontrol kognitif dan kontrol keputusan. Responden yang mengisi instrumen tersebut adalah siswa kelas XI IPS di SMAN 1 Batipuh.

Pada awalnya responden diberikan instrumen kontrol diri untuk melihat kontrol diri rendah, kemudian setelah didapatkan hasilnya, responden diberikan treatment konseling kelompok menggunakan pendekatan cognitive behavior therapy sebanyak 6 kali treatment. Kemudian setelah diberikan treatment diberikan lagi instrumen yang sama kepada responden tersebut untuk melihat apakah ada pengaruh konseling kelompok pendekatan Cognitive Behavior Therapy untuk meningkatkan kontrol diri siswa. Berikut adalah analisis data pretest dan posttest: 
Tabel 1. Distribusi Data Pretest dan Post-Test

\begin{tabular}{|c|c|c|c|c|c|c|}
\hline \multirow{2}{*}{ No } & \multirow{2}{*}{ Subjek } & \multicolumn{2}{|r|}{ Pretest } & \multicolumn{2}{|c|}{ Post-Test } & \multirow{2}{*}{$\begin{array}{c}\text { Peningkatan } \\
\text { Skor }\end{array}$} \\
\hline & & Skor & Kategori & Skor & Kategori & \\
\hline 1 & RFH & 12 & Rendah & 16 & Tinggi & 4 \\
\hline 2 & $\mathrm{SN}$ & 11 & Rendah & 15 & Tinggi & 4 \\
\hline 3 & $\mathrm{BNF}$ & 11 & Rendah & 16 & Tinggi & 5 \\
\hline 4 & AFI & 12 & Rendah & 17 & Tinggi & 5 \\
\hline 5 & $\mathrm{AT}$ & 11 & Rendah & 14 & Tinggi & 3 \\
\hline 6 & FS & 11 & Rendah & 15 & Tinggi & 4 \\
\hline 7 & $\mathrm{HN}$ & 12 & Rendah & 16 & Tinggi & 4 \\
\hline 8 & PS & 12 & Rendah & 15 & Tinggi & 3 \\
\hline 9 & $\mathrm{MZ}$ & 10 & Rendah & 15 & Tinggi & 5 \\
\hline 10 & $\mathrm{NM}$ & 12 & Rendah & 17 & Tinggi & 5 \\
\hline Jumlah & & , 114 & \multirow[b]{2}{*}{ Rendah } & 156 & \multirow{2}{*}{ Tinggi } & \\
\hline Rata-rata & & 11,4 & & 15,6 & & \\
\hline
\end{tabular}

Berdasarkan tabel di atas, dapat dijelaskan bahwa sampel pada penelitian ini mengalami peningkatan jumlah skor kontroldiri. Sebelum treatment jumlah skor 114 dengan rata-rata skor 11,4 setelah diberikan treatment jumlah skor meningkat menjadi 156 dengan rata-rata skor 15,6.

Setelah diketahui hasil pretest dan post-test keseluruhan dari kelompok eksperimen tersebut, maka untuk melihat signifikan atau tidaknya pengaruh konseling kelompok pendekatan cognitive behavior therapy dalam meningkatkan kontroldirisiswa dilakukan dengan analisis uji beda (ujit).Dengan df $=\mathrm{N}-1,10-1=9$ diperoleh harga kritik " $\mathrm{t}$ " pada $\mathrm{t}_{\mathrm{t}}$ dengan taraf signifikansi $0,5 \%$ yaitu sebesar 1,83. Menarik kesimpulan dengan membandingkan besarnya $\mathrm{t}$ yang diperoleh $t_{o}(16,8)>t_{t}(1,83)$ pada $\mathrm{db}=9$ taraf signifikasi $0,5 \%$. Dengan demikian, maka hipotesis alternatif $\left(\mathrm{H}_{\mathrm{a}}\right)$ diterima dan $\left(\mathrm{H}_{\mathrm{o}}\right)$ ditolak pada taraf signifikan $0,5 \%$ dengan db atau df 9 . Ini berarti bahwa konseling kelompok pendekatan cognitive behavior therapy berpengaruh signifikan dalam peningkatan kontroldirisiswakelas XI IPS di SMAN 1 Batipuh.

Kemudian untuk mengetahui berapa persen peningkatan dari pretest ke postest pada setiap anggota kelompok dapat dilakukan dengan rumus N-Gain. Setelah dilakukan gain ternormalisasi pada rata-rata skor angket awal dan angket akhir diperoleh nilai $N$-Gain 0,33. Hal ini menunjukkan rerata kontroldirisiswa berada pada selang $0,30 \leq \mathrm{g} \leq 0,70$ dengan kategori sedang.

\section{DISKUSI}

Penelitian ini bertujuan untuk mengetahui pengaruh konseling kelompok pendekatan Cognitive Behavior Therapy dalam meningkatkan kontrol diri siswa kelas XI IPS SMAN 1 Batipuh.

Berdasarkan hasil analisis data, diperoleh hasil penelitian yaitu terdapat pengaruh signifikan konseling kelompok pendekatan Cognitive Behavior Therapy untuk meningkatkan kontrol diri siswa. Hal ini sesuai dengan penelitian yang dilakukan oleh Ena Yuslaini Siregar dan Rodiatul 
Hasanah Siregar (2013) yang menunjukkan bahwa CBT dapat diterapkan untuk mengurangi durasi individu dalam bermain games pada individu yang mengalami games addiction yang didalamnya terdapat perubahan kognitif yang terdistorsi menjadi lebih rasional melalui teknik cognitive restructuring yang dikombinasikan dengan modifikasi perilaku untuk menguatkan perilaku yang diinginkan. Menurut Spieglerdan Guevremont (dalam Ena Yuslaini, 2013:3) "Cognitive Behavior Therapy merupakan psikoterapi yang berfokus pada kognisi yang dimodifikasi secara langsung, yaitu ketika individu mengubah pikiran maladaptifnya (maladaptive thought) maka secara tidak langsung juga mengubah tingkah lakunya yang tampak (over action)."

Berdasarkan penjelasan diatas dapat dipahami bahwa pendekatan Cognitive Behavior Therapy merupakan sebuah terapi yang menekankan pentingnya peranan kognitif terhadap apa yang kita lakukan. Keduanya saling mempengaruhi ketika seseorang berpikir maka mereka juga bertindak, dan ketika mereka bertindak maka mereka juga berpikir. Dalam kehidupan sehari-hari individu dalam berperilaku dan bertindak perlu mengontrol dirinya dengan baik, maka individu harus memiliki kontrol diri.

Berdasarkan penelitian yang peneliti lakukan, maka hasil yang didapatkan adalah hipotesis alternatif $\left(\mathrm{H}_{\mathrm{a}}\right)$ diterima dan hipotesis nol $\left(\mathrm{H}_{0}\right)$ ditolak. Hal ini dapat dilihat dari besarnya " $t$ "hitung yang peneliti peroleh $\left(\mathrm{t}_{0}=16,8\right)$ dan besarnya " $\mathrm{t}$ "tabel yang tercantum pada $\mathrm{t}_{\mathrm{t}}$ yaitu 1,83 pada $\mathrm{db} 9$ taraf signifikansi 0,5\%. Ini berarti konseling kelompok pendekatan Cognitive Behavior Therapy berpengaruh dalam meningkatkan kontroldirisiswa.

Berdasarkan penelitian yang telah dilaksanakan terlihat bahwa konseling kelompok pendekatan Cognitive Behavior Therapy berpengaruh untuk peningkatan kontroldirisiswakelas XI IPS SMAN 1 Batipuh. Diketahui bahwa 10 orang siswa memiliki kontroldirirendah. Untuk itu siswatersebut diberikan treatment berupa konseling kelompok pendekatan Cognitive Behavior Therapysebanyak 6 kali treatment dan ternyata konseling kelompokpendekatan Cognitive Behavior Therapyberpengaruh terhadap peningkatan kontroldirisiswa.

Hal tersebut terbukti melalui peningkatan skor pretest ke skor post-test, pada skor pretest jumlah skor anak asuh adalah 114 dengan rata-rata 11,4 dengan kategori rendah sebanyak 10 orang siswa. Sedangkan pada skor post-test terjadi peningkatan skor menjadi 156 dengan rata-rata 15,6 dengan kategori tinggi.Hal ini disebabkan karena siswa sungguh-sungguh dalam melaksanakan treatment yang diberikan peneliti.

Selanjutnya terdapat 8 orang siswa yang memiliki peningkatan dalam kategori sedang, hal ini di pengaruhi oleh faktor psikologis yaitu siswa sungguh-sungguh dalam mengikuti treatment yang diberikan, dan siswa berusaha untuk mengontrol kognitif nya sebelum bertindak.Sedangkan peningkatan dalam kategori rendah ada 2 orang siswa, hal ini disebabkan karena siswa masih 
belum bisa mengontrol kognitifnya sebelum bertindak, mereka cenderung tergesa-gesa dalam bertindak.

Dalam penelitian ini kontrol diri terdiri dari dua aspek yaitu aspek kontrol kognitif dan aspek kontrol keputusan, dilihat dari hasil N-gain aspek kontrol kognitif berada pada kategori rendah $(0,17)$, hal ini disebabkan karena siswa pada umumnya sebelum bertindak mereka lebih cenderung tergesa-gesa tanpa memikirkan terlebih dahulu apa yang akan dilakukannya. Hal ini sesuai dengan pendapat Gladding (2012:273) bagaimana seseorang menjelaskan suatu situasi pada umumnya terlihat pada kognisinya (pikiran dan gambaran visual), oleh karena itu tingkah laku yang tidak fungsional disebabkan oleh pikiran yang tidak fungsional.

Dilihat dari hasil N-gain pada aspek kontrol keputusan berada pada kategori sedang $(0,45)$, hal ini disebabkan karena siswa pada umumya kurang bisa mengambil keputusan dengan baik, sehingga dia berperilaku tidak berdasarkan dengan keputusan yang tepat. Sesuai dengan pendapat Siagian (dalam Dimas Aditya R, 2017:3) bahwa pengambilan keputusan adalah suatu pendekatan sistematis terhadap hakik atalternatif yang dihadapi dan menentukan alternatif yang matang untuk mengambil tindakan yang paling tepat.

Dari treatment yang peneliti lakukan didapat kesimpulan bahwa konseling kelompok pendekatan Cognitive Behavior Therapy dapat meningkatkan kontrol diri siswa kelas XI IPS SMAN 1 Batipuh.

\section{KESIMPULAN}

Berdasarkan hasil yang telah diperoleh dari 10 orang sampel sebelum diberikan treatment terdapat 10 orang siswa memiliki kontrol diri rendah. Dari bimbingan dan konseling yang sudah dilakukan bahwa peningkatan setiap siswa berbeda-beda, ada yang meningkat menjadi sedang, ada yang meningkat menjadi tinggi, artinya pengaruh konseling kelompok pendekatan Cognitive Behavior Therapy terhadap kontrol dir siswa di SMAN 1 Batipuh setiap siswa memiliki peningkatan yang tidak sama.

\section{REFERENSI}

Aroma, I.S dan Suminar, D.R. 2012. Hubungan Antara Tingkat Kontrol Diri Dengan Kecenderungan Perilaku Kenakalan Remaja. Jurnal Psikologi Pendidikan dan Perkembangan. $1(2): 3$

Bradley, E.T. 2015. 40 Teknik yang Harus Diketabui Setiap Konselor (edisi kedua). Pustaka pelajar. Yogyakarta 
Darimis. 2014. Model-Model Konseling. STAIN Batusangkar Press. Batusangkar

Desmita. 2006. Metode Penelitian. STAIN Batusangkar Press. Batusangkar

Ghufron, M. N dan Risnawita, S.R, 2010. Teori-Teori Psikologi. Ar Ruzz Media. Yogyakarta

Gladding, S,T. 2012. Konseling profesi yang menyeluruh. PT Indeks. Jakarta

Habsy, B.A. 2017. Model Konseling Kelompok Cognitive Behavior untuk Meningkatkan Self Esteem Siswa SMK. Universitas Darul 'Ulum Jombang. 31(1): 4

Kharunnisa, A. 2013. Hubungan Religiusitas dan Kontrol Diri dengan Perilaku Seksual Pranikah Remaja di MAN 1 Samarinda. Jurnal Psikologi. 1(2): 2

Megalia.Y.AD. 2016. Pengaruh Konseling Cognitive Behavior Therapy dengan Teknik Self Control untuk Mengurangi Perilaku Agresif Peserta Didik Kelas VIII di SMPN 9 Bandar Lampung Tahun Pelajaran 2016/2017. Jurnal Bimbingan dan Konseling. 3(2): 187-200

Muniroh, N.L. 2013. Hubungan Antara Kontrol Diri dan Perilaku Disiplin pada Santri di Pondok Pesantren. Skripsi: UIN Sunan Kalijaga Yogyakarta

Noor, J. 2012. Metodologi Penelitian. Kencana Prenada Media Group. Jakarta

Nurihsan, A.J. 2009. Strategi Layanan Bimbingan dan Konseling. Refika Aditama. Bandung

Rahmawati, A. 2013. Hubungan Antara Pengendalian Diri dengan Perilaku Membolos pada Siswa. Skripsi: Universitas Muhammadiyah Surakarta

Rizal, A.M. 2018. Penerapan Teknik Thought Stopping untuk Mengatasi Remaja Pencandu Minuman Keras. Skripsi: Universitas Islam Negeri Sunan Ampel Surabaya

Rofiq, A.A. 2012. Terapi Islam dengan Strategi Thought Stoppingi dalam Mengatasi Hypochondriasis.Jurnal Bimbingan dan Konseling Islam. 2(1): 65-74

Setiawati, D. 2015. Penerapan Terapi Multimodal dengan Teknik Thought Stopping dan Desensitisasi Sistematik untuk Meningkatkan Harga Diri yang Rendah pada Siswa Kelas VIII SMPN 4 Pasuruan. Universitas Negeri Surabaya. 5(3): 10

Siregar, E.Y. 2013. Penerapan cognitive behavior therapy terhadap pengurangan durasi bermain games pada individu yang mengalami games addiction. Jurnal Psikologi. 9(1):19

Sugiyono, 2013. Metodologi penelitian (pendekatan kuantitatif, kualitatif, dan R※D. Alfabeta. Bandung

Suryabrata, S. 2011. Metodologi Penelitian. Raja Grafindo Persada. Jakarta

Tarigan, M.A. 2016. Hubungan Antara Kontrol Diri dengan Kecenderungan Agresivitas pada Remaja di SMK Negeri 3 Yogyakarta. Skripsi. Universitas Muhammadiyah Yogyakarta

Titisari, H.T. 2017. Hubungan Antara Penyesuaian Diri dan Kontrol Diri dengan Perilaku Delikuen pada Siswa SMA Muhammadiyah 1 Jombang. Psikodimensia. 16(2): 135

Ulandari, Y., \& Juliawati, D. (2019). Pemanfaatan layanan bimbingan kelompok untuk meningkatkan kecerdasan emosi siswa. Indonesian Journal of Counseling and Development, 1(1), 18.

Yandri, H., Alfaiz, A., \& Juliawati, D. (2019). Pengembangan Keterampilan Berpikir Positif melalui Layanan Konseling Kelompok bagi Anggota Ikatan Mahasiswa Pemuda Pelajar Semurup, Kota Padang. Jurnal Pengabdian Pada Masyarakat, 4(4), 509-516.

Yusuf, U dan Setianto, L. 2013. Efektivitas Cognitive Behavior Therapy Terhadap Penurunan Derajat Stress. Fakultas Psikologi UNISBA. 29(2): 177 